have been drawn up with the view of giving as much accurate information as is at present available on the subject of the total area of forests ; total volume of standing timber and increment; output of homegrown woods and of imports and exports for pre-war years, and each of the war years; and the effect of the war-time exploitation on forest capital and the future increment.

Owing to the very heavy war fellings made in countries both within the British Empire and outside, it is probable that accurate figures will not be available for some time to come. Moreover, in many of the forests under the Colonial Office, which are tropical forests containing numbers of different species of tree, very little is yet known about the actual volume present of commercially utilizable timber, and many of them have had to bear heavy war fellings in the accessible parts.

A most interesting paper was prepared by $\mathbf{M r}$. Lyle F. Watt, chief of the Forest Service, United States Department of Agriculture, entitled "The Forest Situation in the United States". Reports were made on the steps taken to carry out the resolutions of the 1935 Conference. These resolutions were nine in number, and for the information available the summary report should be consulted.

Technical committees were appointed as follows: (a) Land Use ; (b) Forest Management, Sylviculture and Protection; (c) Forest Products Research; $(d)$ Survey and Resources; (e) Education; (f) Timber Supply.

Various resolutions were drawn up by these different committees and submitted to the main Conference at its final meeting on July 19. The next Conference will take place in 1952, either in India or Canada.

\section{MAGNETIC FIELD OF MASSIVE ROTATING BODIES}

$I^{\mathrm{T}}$ may be permissible to add a footnote to the much-discussed article by Blackett ${ }^{1}$, in which he examines the proportionality. which seems to exist between the magnetic moment and angular momentum of massive rotating bodies such as the earth, sun and stars. He suggested that this simple result must have some profound physical significance, but that it seemed very probable that a satisfactory explanation would not be found except within the structure of a unified field theory. The purpose of this note is to direct attention to the claim of Prof. J. Mariani, of the Princeton Institute of Advanced Study, to have provided such an explanation and such a unified field theory. Mariani's more accessible publications appeared in C.R. Acad. Sci. Paris, 206, $1247(1938) ; 211,430(1940) ; 218,447$ and 585 $(1944)$; and "Electromagnétisme et relativité" (Cahiers de Physique Théorique, Paris, 1945), Part 1. However, the present summary has been prepared from his latest work, "Théorie des champs macroscopiques"', and a communication submitted to Nature for publication among "Letters to the Editors".

Mariani's latest treatment starts from philosophic considerations, akin to those of Kant, concerning the impossibility of knowing 'the thing in itself'. From the point of view of the average physicist, this is unfortunate. Even if he has the patience to read it, he may merely draw the depressing conclusion that no objective scientific measurement can exist. Thp next section of the work is something like a generalized theory of relativity, but with many coefficients that are quite indeterminate. Then suddenly, by means of a principle of identification, the treatment becomes much more definite. All the equations, except one, reduce to something like the ordinary gravitational theory of relativity. The one exception is the distinctive point of the theory, and its significance seems to be that a gravitational field must necessarily be accompanied by an electrical field.

The application of the theory to massive rotating bodies then proceeds very much on the lines of Sutherland, whose work is discussed in Blackett's article. The earth is supposed to have a positive volume charge compensated by a negative surface charge. This gives the desired proportionality between magnetic moment and angular momentum. The constant of proportionality is worked out for the earth, the sun, and the milky way, and shown to be of the right order of magnitude. It is also shown that for a copper sphere of radius $10 \mathrm{~cm}$. making 200 revolutions per second, the magnetic field is too small to be observed. This agrees with the experiment of Swann and Longacre, also discussed by Blackett.

Those who are interested in the matter will wish to examine Mariani's arguments for themselves; they will probably find the four short papers in Comptes Rendus easier to understand than the fuller and more philosophic version.

H. T. H. Piaggio

${ }^{1}$ Blackett, Nature, 159, 658 (1947).

Théorie des champs macroscopiques. Par Jean Mariani. Pp. ii +98 . (Paris : Centre de Documentation universitaire, 1947.) n.p.

\section{RECENT SOCIOLOGICAL PERIODICALS}

A PART from the specialized field of economics, A Britain has, until recently, suffered from a lack of journals devoted to the social sciences. The deficiency is now being made up by a variety of periodicals. Pilot Papers, as their subtitle of "Social Essays and Documents" suggests, usually take a wide sweep; but the number for June 1947 is devoted largely to American sociology. It contains a detailed review, by Dr. E. A. Shils, of recent American contributions to urban sociology, class stratification and race, family and small group problems, for which all students must be profoundly grateful. There is also an admirable study of the American child by $\mathrm{Mr}$. Gorer, stressing the dictatorship of such factors as the 'scientific feeding schedule' and the fear of being thought a 'sissy'.

American-type sociology is distinguished by using induction from collections of observed fact rather than philosophical deduction. Its methods are thus more akin to those of the natural sciences than the methods of the sociology and economics mainly pursued in Europe. The facts observed may be opinions and attitudes, and one welcomes the first volume of the International Journal of Opinion and Attitude Research, edited by Prof. Radvany, of the University of Mexico, with contributions from $H$. D. Lasswell, Henry Link and Tom Harrisson. The facts observed may also be the behaviour of human beings one to another, and to study behaviour as well as attitudes, a new journal, Anglo-American rather than fully international, is being launched under the title of Human Relations. The first number contains an 
intriguing article by the late Kurt Lewin, a leader in sociological thought and technique as yet almost unknown in Britain. To an equilibrium economist his reduction of such social situations as unhappy marriages, restriction of industrial output or, aggressiveness among boys to an equation of conflieting forces must be interesting and flattering. Human Relations also contains a survey of prejudice in a seaside town, and studies of the civil resettlement of British prisoners of war, and of a scheme for residential management in treating difficult children. The theoretical essays are thus well balanced by articles descriptive of current procedures. Occasionally, as in an unnecessarily complicated account of a fairly simple experiment in industrial training, the writing is wordy and pedantic.

The wide field of contemporary social activity now being approached in the scientific mood is clearly illustrated in these current periodicals. Quite apart from their admirable American articles, Pilot Papers contain in the two numbers for June and September 1947 a much-needed analysis of bureaucrat behaviour, of B.B.C. 'third programme' listening and of the conception of progress in general (by Dr. Julian Huxley) and its practice in agriculture in particular. There are also first-hand experiences of service on a jury, the 'closed shop', and rent tribunal procedure. We look forward to further numbers of all these ventures in modern sociology. P. Sargant Florence

\section{NORTHERN IRELAND FISHING INDUSTRY DEVELOPMENTS DURING THE WAR YEARS}

$\mathrm{P}$

RIOR to the outbreak of the Second World War, the inhabitants of Northern Ireland exported to Grear Britain most of the fish they caught, and imported from Britain most of the fish that they ate. During the war years, however, the consuming public became much more dependent on their own locally caught fish and only surpluses were exported.

In a "Report on Sea and Inland Fisheries", recently published by the Government of Northern Ireland*, these and other war-time changes are reported. As no figures of production and trade exchange could be published during the War because of the statistical 'blackout', this report includes tables for the six-year period 1939-44.

The developments that took place in the Northern Ireland fishing industry during the years under review are indicated by the fact that herring catches in 1944 totalled 50,895 cwt. as compared with 39,467 cwt. in 1938 , and whiting catches rose from $17,061 \mathrm{cwt}$. in 1938 to no less than $64,619 \mathrm{cwt}$. in 1944. The total value of fish (excluding salmon) landed on the coast in 1944 was $£ 258,427$.

Taking all kinds into account, the quantities of sea fish landed in 1944 increased to approximately double the pre-war figure. The total number of fishing boats in Northern Ireland was 508 in 1944, a decrease of 51 boats compared with 1938. Motor boats, however, increased from 314 to 338 in this period, and vessels solely engaged in fishing increased from 109 to 149 in 1944. The number of men em. ployed in sea fishing increased from 898 to 1,031 ,

* Report on Sea and Inland Fisheries, 1942-1944. Pp. 20. (Belfast: H.M. Stationery Office, 1947.) 18. net. of which latter figure 555 were whole-time fishermen, the highest number to be so engaged since the year 1930. The chief factor in this increase in the number of fishermen was the main County Down fleet, which increased from 45 vessels in 1938 to 56 in 1944 .

The report states that the scheme of loans and conditional grants authorized in 1941, combined with greatly increased earnings by fishermen, gave the necessary incentive for the replacement of older craft by vessels of modern design. By the end of 1944, a substantial number of new craft designed for herring fishing and seine netting was either in commission or under construction in spite of war-time shortages. In the years covered by the report, loans exceeding $£ 24,000$ were advanced by the Ministry.

There is also a year-by-year review of inland fishing. Reference is made to the fact that in several hatcheries artificial propagation of salmon was carried out. The year 1943 was the best pollan season in Lough Neagh since 1927. High prices in crossChannel markets greatly helped to stimulate the activities of the freshwater fishermen. On account of the scarcity of fish in Great Britain, considerable impetus was given to the capture of coarse fish in rivers and lakes in Northern Ireland. In the Lough Erne district alone, the total exports of coarse fish in 1944 increased to almost a hundred tons.

\section{FORTHCOMING EVENTS}

\author{
(Meetings marked with an asterisk * are open to the public)
}

Monday, March 22

Assoclation of APPLIED Brologists (in the Botany Lecture Theatre, Imperial College of Science, South Kensington, London, S.W.7), at 11 a.m.-Discussion on "Biological Aspects of Water Pollution"."

RoYal Geographical Society (at Kensington Gore, London, S.W.7), at 5.30 p.m.-Dr. K. M. Strom: "The Geomorphology of Norway".

INSTTTUTION OF THE RUBBER INDUSTRY, MANCHESTER SECTION (at the Engineers' Chub, Albert Square, Manchester), at 6.15 p.m.Mr. T. J. Meyrick and Dr. J. T. Watts: "Polyisocyanates-some Applications in Bonding".

\section{Tuesday, March 23}

Manchester Geographical Society (in the Geographical Hall, St. Mary's Parsonage, Manchester), at 6.30 p.m.-Miss K. Speight: "Sicily, the Garden of the Mediterranean".

TEXTILE INSTITUTE, LONDON SECTION (at the Royal Society of Arts, John Adam Street, Adelphi, London, W.C.2), at 6.30 p.m.Mr. F. Courtney Harwood: "The History and Science of Washing". SHEFFIELD METALLURGICAL ASSociation (at 198 West Street Sheffield, at 7 p.m.-Dr. N. P. Allen: "Some Techniques and Results in Metallurgical Research".

\section{Wednesday, March 24}

BRITISH SOCIETY FOR INTERNATIONAI BIBLIOGRAPHX (at the Institution of Electrical Engineers, Savoy Place, Victoria Embank ment, London, W.C.2), at 2.30 p.m.-Users' Questions on the Universa Decimal Classification Answered.

PALESTINe HodSE (at 18 Manchester Square, London, W.1), at 5.45 p.m.-Dr. Clay Lowdermilk: "The Jordan Valley Scheme"." ROYAL MICROSCOPICAL SOCIETY, INDUSTRIAL MICROSCOPY SECTION (at B.M.A. House, Tavistock Square, London, W.C.1), at 6 p.m.Mr. H. L. Shipp : "The Microscopy of Food".

SOCIETY OF Chemical INDUSTRY, NUTRITION PANEL OF THE FOOD GrodP (joint meeting with the BRITISH DIETETIO ASSOCIATION, at th Chemical Society, Burlington House, Piccadilly, London, W.1), at 6 p.m.-Dr. D. P. Cuthbertson and Miss R. M. Simmonds: "Special Dietary Requirements in Sickness and Convalescence".

Socinty of DYers and Colodrists, Midlands Section (at the Victoria Station Hotel, Nottingham), at 7 p.m.-Mr. G. H. Lister : "The Absorption of Acid and Chrome Dyes by Wool";

CHEMICAL SOCIETY, ABERDEEN SECTION (joint meeting with the LOCAL SECTIONS of the ROYAL INSTTTUTE OF CHEMISTRY and the SOCIETY OF CHEMICAL INDUSTRY, at Marischal College, Aberdeen), at 7.30 p.m.-Prof. E. E. Turner : "Some Stereochemical Problems".

\section{Thursday, March 25}

BRITish Institution of Radio Enginkers, Midland Section (at the Technical College , The Butts, Coventry), at 6.30 p.m.- Mr. and Time Delay of Transmission Networks". 